\title{
Differential Effects Of Entrepreneurship Education On Entrepreneurial Intention Among Science And Non-Science Students' In Nigerian Polytechnics
}

\author{
${ }^{1}$ IRO-IDORO, Charlotte Bose $\&^{2}$ JIMOH, Tajudeen Adisa \\ Office Technology and Management Department,The Federal Polytechnic, Ilaro, P. M. B. 50,Ilaro, Ogun State,
} Nigeria.

\begin{abstract}
This study assesses the differential effects of entrepreneurship education on entrepreneurial intention among science and non-science students in Nigerian Polytechnics. Two research hypotheses were formulated and tested at 0.05 level of significance. Data were collected using a self-developed Entrepreneurial Perception and Intention Scale (EPIS). The population was stratified and purposive sampling technique was adopted through which 400 HND Students from the Federal Polytechnic, Ilaro and Moshood Abiola Polytechnic, Abeokuta both in Ogun State, Nigeria. 200 HND students of the Federal Polytechnic Ilaro (100 science students and 100 non-science students and 200 HND students of Moshood Abiola Polytechnic (100 science students and 100 non-science students) were randomly selected. Data collected were analyzed using frequency counts, simple percentage and t-test. Results revealed that there is a difference in the entrepreneurship intention of students in science-based programmes and non-science-based programmes. The results also indicated a difference in the entrepreneurship perception of the students from the two different backgrounds which could be a resultant effect on their entrepreneurship intentions, while non-science students showed a tilt towards business-oriented ventures. The study recommended, among others, that institutions and other agencies responsible for entrepreneurship development should redesign the programme to enhance students perception of entrepreneurship and also identify the entrepreneurial intention of the students with a view to developing their drive in that direction and with appropriate interventions.
\end{abstract}

Keywords: Entrepreneurship Education, Entrepreneurial Intention, Entrepreneurship Perception, Sciencebased and Non-science Students.

\section{INTRODUCTION}

In Nigeria, Polytechnic Education plays important roles in developing an entrepreneurial society. Polytechnic instill in their students a sense of understanding of risks and rewards, of business creation and its causes of failures. Thus, students increasingly recognize that in the current economic climate most jobs are rarely "for life". The world of employment is changing; permanence and longevity is no longer a significant feature of career paths: traditional paths have disappeared". This widely held view has led to the speculation that there will be continuing growth in self-employment as a career option for individuals at different stages in life [1]. There is now a widespread recognition that entrepreneurship is the engine that drives the economy of most nations [2].Entrepreneurship is the intentional creation or transformation of an organisation for the purpose of creating or adding value through organisation of resources [3]. As a dynamics process of vision, change and creation, it requires to be taught for the transfer of its skills and knowledge from an expert to someone else. It involves an application of energy and passion towards the creation of an enterprise and this includes the; willingness to take calculative risks; team work; the creative skill to marshal needed resources; fundamental skill of building solid business plan; and finally, the vision to recognize opportunity where others see chaos, contradiction, and confusion [3] \& [4]. Entrepreneurs therefore possess peculiar characteristics required for carrying out successful entrepreneurial ventures. These characteristics may differ depending on the interest. They include; desire for achievement, locus of control; risk taking propensity; proactiveness, tolerance for ambiguity and creativity [5]. These characteristics have become the focus of many researchers in the recent time. Youth often have a special personality. They value the issues of strength, autonomy and independence as important in their desire to become entrepreneurial [6] \& [3]. They perceive change as an opportunity to unleash their potential and are willing to take moderate risks [7]. They have social skills and possess a balance between intuition and thinking [8]. A person's decisions to choose entrepreneurial careers tend to be greatly influenced by the extent to which he or she values these two factors in processing cognition [9]. The key to improving perceptions within society and within higher education according to [1] lies in education, according 
to him, creation theory suggests an opportunity-uncertainty framework in entrepreneurship, reflecting the human tendency to be involved in the evolution from uncertainty to opportunity [9].

The importance of entrepreneurship has made entrepreneurial education to gain worldwide recognition in most developed and developing countries. The development of entrepreneurial skills in education is considered an avenue to increase the supply of future entrepreneurs in any country with the hindsight to alleviate poverty, reduce unemployment, establish new enterprises and reduce the possible failure rate of existing businesses [10]. Entrepreneurial education is regarded a key to the stimulation of both entrepreneurial spirit and thinking among graduates to become creators of wealth not seekers of employment [11]. Entrepreneurial programmes raise attitudes and behaviour capable of provoking entrepreneurial intentions among undergraduates [12].From the above, it is an undisputable fact that entrepreneurship education has a lot benefits to offer students, educators, local communities, government at all levels and all Nigerians. However, despite the fact that final year students normally prepare for employment after graduation, a large percentage are usually unable to find jobs after they graduate. Yet, A small percentage of graduates actually become entrepreneurs within a few years after graduation. One way to explain entrepreneurial intention levels is by means of motives [13] whereas, policy goals usually do not correspond with the motives of enterprising individuals [14]. Hence, it becomes more important to understand varying entrepreneurial intentions among students with different discipline in order to achieve an institutional "fit" between higher education offerings and the entrepreneurial needs of students. This is because the totality of the experience that students gain in higher education is, and will be, influenced by many factors, including the prior experiences they have had in education; their personal aspirations for the future; their expectations concerning their life while in school; and how their experience in school supports their future aspirations [15].

The perspectives and believes of students toward entrepreneurship are the results of their immediate social and educational environment [16]. Consequently, the orientation and conducts of youth and young graduates are affected by various individual and ecological variables, which imply that the decision and desirability of becoming an entrepreneur or employee is a reflection of environmental and economic forces [17]. Many studies have revealed that entrepreneurs are not naturally conceived but made through their environment and experiences as they develop and learn, being impacted by guardian, mentors, tutors, instructors and role model during their development process [17]; [18] \&[19].

The primary aim of this study is to assess the differences in the entrepreneurial intention and perception of students in science-based courses and that of their counterparts in the non-science-based programmes of Nigerian Polytechnics, with emphasis on the Federal Polytechnic, Ilaro and Moshood Abiola Polytechnic,Abeokuta both in Ogun State, Nigeria. The study attempted to establish if the entrepreneurial drive of students differs across background disciplines and how this influence their perception about entrepreneurship and their intention to create, run and manage their own businesses.

\section{STATEMENT OF THE PROBLEM}

The rate of unemployment situation in Nigeria today is becoming worrisome to both the government and the populace. The problem is compounded by factors such as, job losses and almost zero employment growth rates in most government and private business establishment. It is therefore important to assess the perceptions of final year students towards entrepreneurship across the different faculties or fields of study. If perceptions and knowledge differ across fields, it may motivate for some differences in entrepreneurship intentions. Thus, this study investigated the differences, engendered by the entrepreneurship education or training, on the entrepreneurship intentions of students in Nigerian Polytechnics. It specifically examines the entrepreneurship perception and intention among students of different background disciplines with special emphasis on the students of science-based programmes and non-science based programmes of the Polytechnics in Nigeria.'

\section{OBJECTIVES OF THE STUDY}

The purpose of this study was to investigate the entrepreneurial perception of students in science-based programme and non-science-based programmes and entrepreneurial intention of students in science-based programmes and non-science-based programmes in Polytechnics in Nigeria.

\section{RESEARCH HYPOTHESES}

The following null hypotheses were formulated and tested at 0.05 level of significance:

1.There is no significant difference in the entrepreneurial perception of students in science-based programmes and non- science based programmes.

2.There is no significant difference in the entrepreneurial intention of students in science-based programmes and non- science based programmes. 


\section{METHODOLOGY}

This study is a descriptive research that employed the use of questionnaire. Higher National Diploma Students of the Federal Polytechnic, Ilaro and Moshood Abiola Polytechnic, Abeoukata both in Ogun State Nigeria constituted the population. The population was stratified and purposive sampling technique was adopted through which 400 HND Students from the Federal Polytechnic, Ilaro and Moshood Abiola Polytechnic, Abeokuta both in Ogun State, Nigeria were randomly selected (200 HND students of the Federal Polytechnic Ilaro and 200 HND students of Moshood Abiola Polytechnic). The population was stratified into science-based and non-science-based students. The study adopted purposive sampling through which 100 HND students from the science-based programmes and $100 \mathrm{HND}$ students from the non-science based programmes of the Federal Polytechnic, Ilaro and $100 \mathrm{HND}$ students from the science-based programmes and 100 HND students from the non-science based programmes of Moshood Abiola Polytechnic, Abeokutawere randomly selected. All the questionnaires administered were completed and returned by the students. The Science-based students were selected from the School of Applied and Pure Sciences, Engineering and Environmental Studies while the nonscience based students were selected from the departments in the School of Management Studies. The research instrument used in gathering data for the study is questionnaire tagged Entrepreneurship Perception and Intention Scale (EPIS). The EPIS was made up of three sections; section A sought demographic information on students' level, department and faculty, Section B contained structures items meant to elicit information on the perception of the students on entrepreneurship while Section C contains items to elicit information on their entrepreneurship intentions. The reliability and validity of the questions in the questionnaire had been established in previous studies by Walstad and Kourilsky (1998). The questionnaire items were adapted to suit this study and was piloted with final year students of Moshood Abiola Polytechnic, Ogun State before being administered to the sample.

\section{RESULTS AND DISCUSSION}

Data collected were analyzed using simple percentage and frequency counts and t-test of significance.

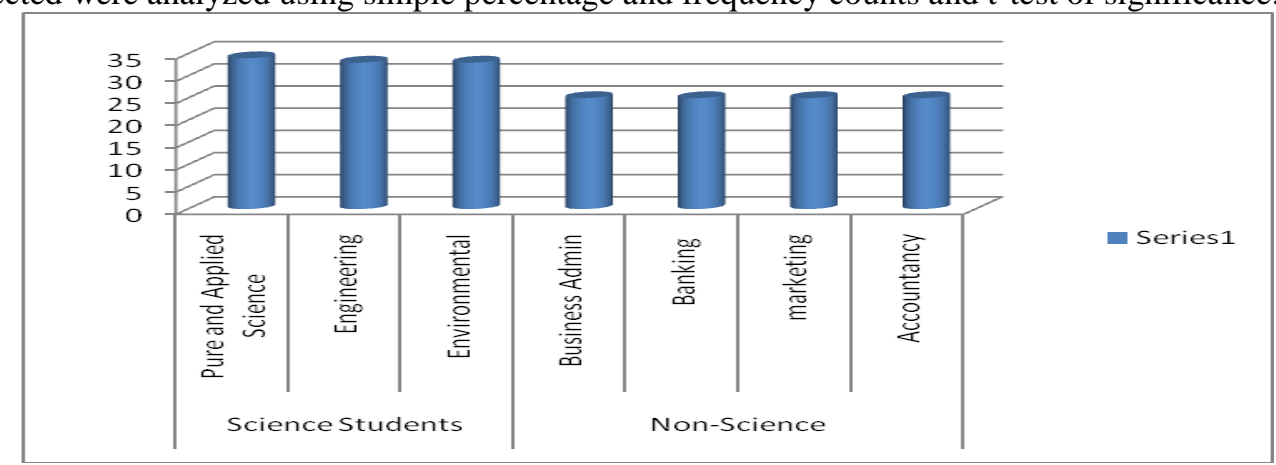

\section{Distribution of Respondents by programmes}

In the above chart, three schools that offer science-based programmes were involved in the study, 68 students were selected from Pure and Applied Sciences, 66 from Engineering and 66 from Environmental Studies. In the non-science based school, three were being run and the selection covers the four programmes such that 50 students each were selected from each programme.

\begin{tabular}{|c|c|c|c|c|c|}
\hline & & Mean & $\mathrm{N}$ & $\begin{array}{c}\text { Std. } \\
\text { Deviation }\end{array}$ & $\begin{array}{l}\text { Std. Error } \\
\text { Mean }\end{array}$ \\
\hline \multirow[t]{2}{*}{$\begin{array}{l}\text { Pai } \\
\text { r } 1\end{array}$} & $\begin{array}{l}\text { I prefer starting my } \\
\text { own business }\end{array}$ & 2.59 & 400 & .947 & .067 \\
\hline & $\begin{array}{l}\text { I prefer starting my } \\
\text { own business }\end{array}$ & 2.79 & 400 & .927 & .066 \\
\hline \multirow[t]{2}{*}{$\begin{array}{l}\text { Pai } \\
\text { r } 2\end{array}$} & $\begin{array}{l}\text { Being an } \\
\text { entrepreneur is } \\
\text { better than salary } \\
\text { work }\end{array}$ & 2.62 & 400 & .960 & .068 \\
\hline & $\begin{array}{l}\text { Being an } \\
\text { entrepreneur is } \\
\text { better than salary } \\
\text { work }\end{array}$ & 2.94 & 400 & .891 & .063 \\
\hline
\end{tabular}


Source: SPSS Analysis of Field Data 


\begin{tabular}{|c|c|c|c|c|c|c|c|c|c|}
\hline \multicolumn{10}{|c|}{ Table 2: Paired Samples Test } \\
\hline & & \multicolumn{5}{|c|}{ Paired Differences } & \multirow[t]{3}{*}{$\mathrm{t}$} & \multirow{3}{*}{$\begin{array}{l}D \\
f\end{array}$} & \multirow{3}{*}{$\begin{array}{l}\text { Sig. } \\
(2- \\
\text { tailed) }\end{array}$} \\
\hline & & \multirow[t]{2}{*}{$\begin{array}{l}\mathrm{M} \\
\mathrm{e} \\
\mathrm{a} \\
\mathrm{n}\end{array}$} & \multirow[t]{2}{*}{$\begin{array}{c}\text { Std. } \\
\text { Devi } \\
\text { atio } \\
n\end{array}$} & \multirow{2}{*}{$\begin{array}{l}\mathrm{St} \\
\mathrm{d} . \\
\mathrm{Er} \\
\text { ror } \\
\mathrm{M} \\
\text { ea } \\
\mathrm{n}\end{array}$} & \multicolumn{2}{|c|}{$\begin{array}{c}95 \% \\
\text { Confidence } \\
\text { Interval of the } \\
\text { Difference }\end{array}$} & & & \\
\hline & & & & & Lower & $\begin{array}{l}\text { Up } \\
\text { per }\end{array}$ & & & \\
\hline $\begin{array}{l}\mathrm{P} \\
\mathrm{a} \\
\mathrm{i} \\
\mathrm{r} \\
1\end{array}$ & $\begin{array}{l}\text { I prefer } \\
\text { starting } \\
\text { my own } \\
\text { business - } \\
\text { I prefer } \\
\text { starting } \\
\text { my own } \\
\text { business }\end{array}$ & $\begin{array}{l}- \\
.2 \\
0 \\
5\end{array}$ & .822 & $\begin{array}{r}.0 \\
58\end{array}$ & -.320 & $\begin{array}{r}- \\
.09 \\
0\end{array}$ & $\begin{array}{r}- \\
3 . \\
5 \\
2 \\
5\end{array}$ & $\begin{array}{l}1 \\
9 \\
9\end{array}$ & .001 \\
\hline $\begin{array}{l}\mathrm{P} \\
\mathrm{a} \\
\mathrm{i} \\
\mathrm{r} \\
2\end{array}$ & $\begin{array}{l}\text { Being an } \\
\text { entreprene } \\
\text { ur is better } \\
\text { than salary } \\
\text { work - } \\
\text { Being an } \\
\text { entreprene } \\
\text { ur is better } \\
\text { than salary } \\
\text { work }\end{array}$ & $\begin{array}{l}- \\
.3 \\
2 \\
0\end{array}$ & .971 & $\begin{array}{r}.0 \\
69\end{array}$ & -.455 & $\begin{array}{r}.18 \\
5\end{array}$ & $\begin{array}{r}- \\
4 . \\
6 \\
6 \\
2\end{array}$ & $\begin{array}{l}1 \\
9 \\
9\end{array}$ & .000 \\
\hline
\end{tabular}

Source: SPSS Analysis of Field Data

\section{DISCUSSION}

Table above shows the average responses of science and non-science students with respect to entrepreneurship perception and entrepreneurship intention, the result indicates that non-science students are having on average of 2.94 and 2.79 responses while science based students have on average 2.62 and 2.59 .

T-test was employed to test the relationship between the responses of science-based students to that of non-science students; it shows significant value of 0.001 for entrepreneurship intention and 0.000 for entrepreneurship perception. Since these values are less than 0.05 , this is an indication that the alternative hypotheses should be accepted and the null hypotheses should be rejected. The Researchers then conclude that there is significant difference in entrepreneurship intention of science-based students and that of non-science based students. Moreover, on entrepreneurship perception, the alternative hypothesis is also accepted indicating that there is a significant difference between entrepreneurship perception of science-based students and non-science based students. The result is in tandem with [1] that final year students have different perceptions and knowledge about entrepreneurship from gender, race and faculty perspectives.This study has shown that non-science students are likely to be an entrepreneur compared to their science-based counterparts. Students in non-science programmes are more likely to envisage future careers as entrepreneurs and are more positive towards entrepreneurship than their science-based counterparts, they showed the belief that entrepreneurship is an opportunity for them to make use of their potentials, even though motivators for entrepreneurship are similar across the samples, this is in line with [8].Specifically, the questions that played a key role in ascertaining a possible answer to the hypotheses were those which measured likelihood of actually becoming an entrepreneur when and whether this in their beliefs would influence their attitude and entrepreneurial intention. The students indicated different dispositions and attitude which may influence their intentions for entrepreneurial ventures. This study corroborates [11] \& [14] although, this study did not look into the reason for the varying level of entrepreneurial intentions among the two categories of students but the disposition and perceptions of the students may differ depending on their interest and other factors such as risk taking propensity; , social skills, gender, creativity, etc. as observed by [5]. These characteristic factors often times affect the desire to become entrepreneurs. This confirms [6] \& [3] that perceive change as an opportunity to unleash their potential and are willing to take moderate risks [5]. They have social skills and possess a balance between intuition and thinking [8]. 


\section{CONCLUSION}

The central aim of this study is to assess the differences in the entrepreneurship intention of students in science-based programmes and that of their non-science-based programmes of the Polytechnics. From the findings of this study, it is concluded that students from the two background disciplines believe that entrepreneurship education is important. However, there is significant difference in entrepreneurship intention of science- based students and that of non-science based students. Science-based students exhibited low intention to start and run own-business while the non-science based students showed inclination towards starting their own business after graduation.Perceptions towards entrepreneurship was found to be different among students from science-based programmes and non-science based programmes. The reasons for the differences in the entrepreneurship intention and perception of the two backgrounds was not established in the study, but the low inclination of science-based students towards entrepreneurship could be attributed to the fact that they have low perception of entrepreneurship and their belief on institutional framework and support to embark on own businesses.

\section{RECOMMENDATIONS}

- In the design of the entrepreneurship training, efforts should be made to specifically increase the perception of students towards entrepreneurship so as to enhance their attitude towards entrepreneurship training.

- Government should endeavour to provide adequate funding and an enabling environment through the provision of social and economic infrastructures capable of promoting entrepreneurial programmes so as to facilitate the encouragement of graduates to go into entrepreneurship.

- There is also the need to device new teaching techniques in order to improve students' perception.

\section{REFERENCES}

[1] Brijlal P. (2010). Entrepreneurial perceptions and knowledge: A survey of final year university students. African Journal of Business Management, 5(3), 818-825. Retrieved from http://www.academicjournals.org

[2] Gorman, G., Hanlon, D., \& King, W. (1997), Some Research Perspectives on Entrepreneurship Education, Enterprise Education and Education for Small Business Management: a Ten-Year Literature Review. International Small Business Journal. 15(3).

[3] Izedonmi, P. F. \& Okafor C. (2010). The Effect Of Entrepreneurship Education On Students' Entrepreneurial Intentions. Global Journal of Management and Business Research, 10(6).

[4] Krueger, N. (2007). What Lies Beneath the Experiential Essence of Entrepreneurial Thinking, Entrepreneurship, Theory and Practice, 2(4), 123-138.

[5] Bateman, T. \& Shell, S. (1999). Management Building Competitive Advantage. $4^{\text {th }}$ Edition, Boston: Irwin McGraw Hill.

[6] Baum, J. R., Locke, E. A., \& Smith, K. G. (2001). A Multidimensional Model of Venture Growth. Academy of Management Journal, 44(2), 292-303.

[7] Brockhaus, R. H. (1985). The Psychology of the Entrepreneur. Englewood Cliffs: N.J., Prentice Hall.

[8] Yordanona, D. \& Tarrazon, M. (2010). Gender Differences in Entrepreneurial Intentions. Retrieved $5^{\text {th }}$ July, 2016 from http://www.cmr-journal.org.

[9] Jackson, S. (2010). Mulling over massachusetts: Health insurance mandates and entrepreneurs. Entrepreneurship Theory and Practice, 34(5), 909-931. http://dx.doi.org/10.1111/j.1540$\underline{6520.2009 .00351 . \mathrm{x}}$

[10] Peterman N. E, \& Kennedy J. (2003). Enterprise education: influencing students' perceptions of entrepreneurship. Entrepreneurship Theory Pract., 28(2), 29-144.

[11] Linan F. (2004). Perspectives on Entrepreneurial Education: A US-Europe Comparison, Jean Monnet European Studies Centre. Retrieved on 10 $0^{\text {th }}$ July, 2016 from http://www.academia.edu.

[12] Leong, C. K. (2008). Entrepreneurial Intention: An Empirical Study among Open University Malaysia Students. Retrieved on $11^{\text {th }}$ July, 2016 from http://www.academicjournals.org

[13] Davidsson, P. (1995). Determinants of Entrepreneurial Intentions . In Proceedings RENT XI Workshop, Piacenza, Italy. Retrieved from http://eprints.qut.edu.au/archive/00002076.

[14] Thompson, E. R. (2009). Individual entrepreneurial intent: Construct clarification and development of an internationally reliable metric. Entrepreneurship Theory and Practice, 33(3).

[15] David M. C. (2014). Entrepreneurial Perceptions and Intentions: An empirical survey of Students in the Faculty of Commerce at Great Zimbabwe University, Zimbabwe. International Journal of Management Science, 2(1). 
[16] Alain, F., Benoit, G., \& ClercNarjisse, L. (2006). Effect and Counter-effect of Entrepreneurship Education and Social Context on Student's Intentions. Estudios de Economía Aplicada, 24(2), 509-523.

[17] Obembe E., Otesile O. \& Ukpong I. (2014). Understanding the students' perspectives towards entrepreneurship. Procedia - Social and Behavioral Sciences 145, 5-11 Retrieved from http://www.sciencedirect.com

[18] Teixeira A .A. C, \& Forte, R. P (2008). Unbounding entrepreneurial intents of university students: a multidisciplinary perspective. Repec: por:fepwps, 322.

[19] Adetayo, J. O. (2014). An Investigation of the Level of Entrepreneurial Aspiration among Students in a Nigerian University. Research on Humanities and Social Sciences, 4, (11). 